\title{
THE IMPACT OF GLOBAL CHANGE ON MOSQUITO-BORNE DISEASE
}

Lydia H.V. Franklinos ${ }^{1,2 *}$ MSc, Kate E. Jones ${ }^{1,3} \mathrm{PhD}$, David W. Redding ${ }^{1} \mathrm{PhD}$ and Ibrahim Abubakar ${ }^{2} \mathrm{PhD}$.

Affiliations:

${ }^{1}$ Centre for Biodiversity and Environment Research, Division of Biosciences, University College London, Gower Street, London, WC1E 6BT, UK.

${ }^{2}$ Institute for Global Health, University College London, 30 Guilford Street, London, WC1N $1 \mathrm{EH}, \mathrm{UK}$.

${ }^{3}$ Institute of Zoology, Zoological Society of London, Regent's Park, London, NW1 4RY, UK.

*Corresponding author: Lydia Franklinos, Lydia.Franklinos.16@ucl.ac.uk, +44 (0)203 108

7691, Centre for Biodiversity and Environment Research, Division of Biosciences,

University College London, Gower Street, London, WC1E 6BT, UK.

In preparation for submission to the Lancet Infectious Diseases.

Word count ( $\max 4500): 4419$ (4479 including titles)

Abstract word count ( $\max 150): 149$ 


\section{SUMMARY}

Over $80 \%$ of the global population is at risk of a vector-borne disease, with mosquito-borne diseases being the largest contributor to human disease burden. Although many global processes such as land-use and socioeconomic change are thought to influence mosquitoborne disease dynamics, research to-date has strongly focused on the role of climate change. We show, through a review of contemporary modelling studies, that there is no consensus on how future changes in climatic conditions will impact mosquito-borne diseases, possibly due to interacting effects of other global change processes which are often excluded from analyses. We conclude that research should not focus solely on the role of climate change but instead consider growing evidence for additional factors that modulate disease risk. Furthermore, future research should adopt new technologies, including developments in remote sensing and system dynamics modelling techniques, enabling a better understanding and mitigation of mosquito-borne diseases in a changing world. 


\section{THE GLOBAL THREAT OF MOSQUITO-BORNE DISEASE}

Diseases transmitted by arthropod vectors such as mosquitoes and ticks are major contributors to the global burden of infectious disease, ${ }^{1}$ with nearly half the world's human population being infected with a vector-borne pathogen at any moment. ${ }^{2}$ In particular, mosquito-borne diseases (MBDs) are a key group of concern, as they include both very high burden and important emerging diseases such as: Human malaria ( 212 million cases per year), Dengue ( 96 million cases per year), Chikungunya ( 693 000 cases per year) and Zika virus disease $\left(\sim 500,000\right.$ cases per year) $($ Table 1$) .^{3}$

Globally, many MBDs are thought to be increasing in incidence and geographic distribution; both emerging in new areas, ${ }^{4,5}$ and re-emerging in previously eradicated regions. ${ }^{6,7}$ For example, there has been a 30-fold increase in the global incidence of dengue over the past 50 years, following its expansion into many new countries, ${ }^{5,8,9}$ while yellow fever cases are reported to be increasing again in many endemic countries, after previous dramatic declines. ${ }^{7}$ These diseases, with their corresponding high levels of morbidity and mortality, have the potential to exert significant negative financial and societal effects and can dramatically inhibit the development and structure of economies, societies and politics. ${ }^{6}$ As a consequence, much research has been targeted at understanding the current and future geographic distributions of disease risk, in the context of on-going global change, to help guide interventions and safeguard public health. ${ }^{10-12}$

In this context, there has previously been a strong research focus on modelling the direct effects of climate change on spatial and temporal disease risk, ${ }^{13-15}$ paying less attention to other factors that are already known to interact with both climate change and vector-borne diseases, such as land-use and socioeconomics (e.g. poverty, trade and travel). ${ }^{3,16,17}$ Indeed, these additional global processes, and the interactions between them, may reasonably be 
shown to have a stronger immediate impact on future MBD burden than climate change effects. ${ }^{18}$ This would mean a more complete understanding of the role of global change in modulating the spatial and temporal distributions of MBDs will be essential for the successful prediction and management of disease risk in the future. ${ }^{19}$ In this review, we synthesise current knowledge on the relative impact of global change processes on MBD risk and critically examine how these have been incorporated into existing analyses. We argue that the current focus on the effects of climate change is insufficient, considering growing evidence for the key role of other global change processes in modulating MBD risk. We suggest an alternative approach to modelling MBD risk and recommend future directions for research.

\section{CLIMATE CHANGE AS A DRIVER OF MOSQUITO-BORNE DISEASE}

\section{Systematic review of current literature}

We conducted a systematic literature search to better understand the scope and outcome of climate-based MBD modelling studies (search strategy and selection criteria), structuring the search to explore two main axes: First, we considered different mechanisms examined by each study as climate and climate change may affect MBD epidemiology via different pathways, such as influencing pathogen development within the mosquito, and vector population dynamics. ${ }^{20,21}$ Second, we examined how different modelling approaches, such as mechanistic and correlation-based methods, have been used to predict the effect of climate on the risk of multiple MBDs over different geographic and temporal scales. ${ }^{22}$ Within this search we defined climate change as an alteration (either observed or projected) in climatic parameters over several decades, with changes in MBD risk being inferred from variations in disease incidence or vector populations. 
Of 234 papers identified, 46 met the inclusion criteria (Supplementary materials; Table S1). Overall $54 \%$ of studies demonstrated a positive relationship between climate change and MBD risk, with increased variations in meteorological values associated with increased vector abundance or disease incidence. However, the proportion of studies showing this positive relationship varied depending on the geographic scale of the study (Figure 1a). Of those studies that predicted increased disease risk with climate change, less than half included key biological information, such as vector critical climatic thresholds and $28 \%$ considered other global processes (Figure 1b). Global change processes examined in the 46 studies included land use in $17 \%$, human population density in $11 \%$, of which less than half considered future human density projections, and socioeconomics in $7 \%$.

Temperature, precipitation and humidity were the main parameters used to model climate change (Supplementary materials; Table S1). Over 97\% of studies included the effect of temperature change in their analyses, whereas $78 \%$ included precipitation and $22 \%$ considered humidity. Temperature has been a predominant research focus since mosquitoes are ectothermic and so ambient temperature strongly influences important epidemiological processes including vector development, biting rates and pathogen development rate within the vector (Reiter 2001; Mordecai et al. 2017). Precipitation is regularly included as parameters in models of MBD risk as water pools are required for mosquito development and associated humidity levels influence mosquito survival and flight. ${ }^{23,24}$

Changes in these meteorological variables were determined from recorded climatic data or from projected climatic values using different scenarios of climate change (e.g. IPCC emissions). ${ }^{25}$ Regarding modelling approaches, over $50 \%$ of the studies used correlative models to investigate statistical associations between MBD risk and explanatory variables ${ }^{22}$. Other studies used mechanistic models which incorporated biological or environmental mechanisms assumed to drive disease dynamics (e.g., increased rainfall providing water 
pools for vector development). In addition, a few studies combined correlative and mechanistic approaches in hybrid correlative models. Mechanistic models were used more commonly for small geographic area analyses such as zonal and national, compared with correlative methods which tended to be used for large-scale regional or global analyses. Most studies were prospective (i.e., predicting to into future) but a few were retrospective or theoretical.

The overall results indicate that there is no consensus on how changes in climatic conditions will impact MBD risk. This equivocal conclusion may reflect choice of modelling parameters (i.e., selected climatic variables), spatial or temporal scales of the analyses, modelling approach and/or, exclusion of important factors or biological processes from the analyses.

\section{Climate change and mosquito-borne disease risk}

The strong focus on the effects of temperature change in the field of MBD research ${ }^{11,26-28}$ appears to have led to a body of international scientific reports concluding that MBD expansion will likely occur in parallel with climate change. ${ }^{25,29}$ However, the conclusions are based on the assumption that temperature is a robust predictor of mosquito population dynamics, despite many temperature-dependent relationships and their interactions remaining poorly defined. ${ }^{14,30,31}$ For example, the effect of increasing temperature on physiological traits in ectotherms has been shown to be generally non-linear, ${ }^{15,32}$ and can result in negative outcomes such as reduced survivorship, ${ }^{14}$ and fast larval development, resulting in small adult mosquitoes. ${ }^{33}$ Small mosquito body size has been associated with reductions in fecundity, bloodmeal size and immunocompetence. ${ }^{34}$ Therefore, paradoxically, climate change may actually reduce the risk of transmission in certain regions via the negative effects of 
increasing temperatures on vector competence (i.e., the ability of vectors to become infectious).

Temperature also influences the time taken for pathogen development within the mosquito (i.e., extrinsic incubation period [EIP]). ${ }^{15,30}$ The EIP has a major impact on disease transmission because small changes in this parameter can greatly affect the number of mosquitoes that live long enough to become infectious. However, most climate-based MBD models do not include this parameter and when it is included, it is often based on out-dated, temperature-dependent models developed from a single mosquito species that do not consider the influence of other abiotic (e.g., larval habitat quality) or biotic (e.g., parasite competition within the mosquito) factors. ${ }^{35}$ Studies have typically demonstrated EIP to be shortened with increasing temperatures, and suggested related high infection and transmission rates. ${ }^{36-38}$ However, this effect may vary considerably depending on the specific vector and pathogen. ${ }^{35}$ For example, in Aedes vectors, low temperatures have been shown to shorten EIPs and cause high viral infection rates by suppressing mosquito antiviral immunity. ${ }^{33}$ Other studies have found large temperature fluctuations at low mean temperatures cause shorter EIPs and higher infection in vectors of dengue virus ${ }^{39,40}$ and malaria ${ }^{41}$, when compared with more consistent conditions. The lack of clarity about the relationship between EIP and temperature is a critical knowledge gap that requires further empirical research to inform accurate forecasting of MBD risk.

There is considerable debate about how future climate change will impact precipitation trends, ${ }^{42,43}$ but the consensus is that an increasing frequency of extreme precipitation levels is likely. ${ }^{44}$ With regard to MBDs, increased variation in precipitation may either augment vector breeding habitat formation or reduce it via detrimental periods of drought and extreme flooding. Similar to the effects of temperature, the relationship between precipitation and MBD risk is non-linear ${ }^{27,45}$. Several lagged effects (i.e., time-lags between water pooling and 
adult mosquito emergence) need to be considered in any analysis. ${ }^{46}$ Furthermore, precipitation alone does not account for the presence of vector breeding habitat; this will also depend on species-specific preferences (i.e., water depth) and hydrological factors (e.g., as soil type, vegetation) that control temporary water body development. ${ }^{45,47}$ A few studies have incorporated hydrological processes into their regional disease risk models, ${ }^{47-49}$ but the practice has not been widely adopted possibly because of the increased complexity needed to model these processes or lack of collaboration between disease researchers and hydrological experts.

Although climate-based models have proved useful in understanding MBD risk at local scales ${ }^{50}$ and short timescales,${ }^{51}$ models based solely on approximating the impacts of climatic factors are unlikely to be as effective over large spatial and temporal scales. We already know of other important mechanisms that influence the geographic distributions of vector populations, such as dispersal (e.g., via host movement, wind and trade routes), and biotic interactions (e.g., competition and predation). ${ }^{20,52,53}$ For instance, although West Nile Virus was theoretically able to exist in the Americas due to climatic suitability, it was not until 1999 that it spread from its original range in Africa, southern Europe, and Southwest Asia, to the whole of North America, likely due to dispersal by migratory birds ${ }^{53}$ Likewise, Aedes aegypti was expected to occupy rural habitats of southern USA due to climatic suitability, but these predictions proved inaccurate when competitor, Aedes albopictus was present. ${ }^{20}$

The burden of disease from MBDs felt by human populations, therefore, is likely an emergent property of a set of interacting processes which will vary at different spatiotemporal scales. For instance, although climate change is likely to cause some predictable range shifts in vector species ${ }^{54}$ the precise impact of these changes can only be understood in the wider context of a set of non-biological factors, such as land-use change and socioeconomic development. ${ }^{52}$ Such interactions may be additive as demonstrated by the synergistic effects 
of climate change, urbanisation, international trade and travel that have promoted the global expansion in dengue transmission risk. ${ }^{55}$ Alternatively, they may be subtractive as seen with the global malaria recession which has occurred in parallel with increasing urbanisation ${ }^{56}$ and economic development. ${ }^{57}$ The usefulness of climate-based models of MBD risk should not be underestimated however, to predict distributions of MBD risk in the context of on-going global change, there is a need for more complex models that consider multiple global change processes. $^{28}$

\section{THE IMPACT OF LAND-USE CHANGE ON MOSQUITO-BORNE DISEASE}

Land-use change, from natural to human-dominated landscapes, is a key signature of the Anthropocene ${ }^{58}$ and can alter disease risk by influencing the interactions between people, pathogens, vectors and vertebrate hosts..$^{3,17,59-62}$ The immediacy and strength of land-use change impacts on local ecology ${ }^{63}$ supports the argument that it may prove to be the most important driver of recent disease emergence and global spread. ${ }^{3,62,64}$ However, the impact of land-use change on MBD risk will depend on several factors such as its geographic region and mode of the change, i.e., whether it was due to deforestation, agriculture, irrigation, and/or urbanisation. Each of these types of change are discussed below.

\section{Deforestation}

Deforestation has been associated with increased human exposure to MBDs ${ }^{65,66}$ via its effect on the ecology of vertebrate hosts of zoonotic pathogens, vectors, and vector-host interactions. For example, biodiversity declines are associated with primary forest clearance ${ }^{67}$ and may result in shifts in the community composition of wildlife hosts ${ }^{3,60,68}$ and emergence of infectious diseases. ${ }^{64}$ It is postulated that in biodiverse regions, multi-host community structures may be able to buffer against disease outbreaks since pathogen transmission may 
be diluted. ${ }^{69-71}$ Despite the theoretical and empirical evidence for this 'dilution effect' being strongest for vector-borne pathogen transmission, ${ }^{70,72}$ the generality of this theory remains disputed. ${ }^{72-74}$

Since mosquito ecology is dependent on abiotic and biotic environmental conditions, landuse changes will have a significant effect on populations ${ }^{21}$ via altering microclimates, biotic interactions (e.g., predation and competition), and nutrient availability. ${ }^{75}$ Deforestation promotes the growth of certain mosquito populations due to changes in sunlight and $\mathrm{pH}$ of water pools in cleared areas. ${ }^{76}$ For instance, increased sunlight has been shown to assist mosquito survival by providing nutrients for larvae, ${ }^{77}$ and limiting entomophagic fungi growth. ${ }^{78}$ Nevertheless, the effect of these changes on mosquito populations will vary depending on the specific microclimate created and the species' ecology. ${ }^{21}$ Frequently, deforestation has been associated with an increased abundance of mosquitoes that act as vectors of disease, with non-vector species favouring undisturbed forest. ${ }^{75,79}$ The mechanisms behind this remain unclear, but may reflect evolutionary processes that, due to a history of human-mosquito co-occurrence, have enabled pathogens carried by disturbance-specialist mosquito species to adapt to infect humans and proliferate in anthropogenic landscapes. ${ }^{79}$

\section{Agriculture}

Agricultural land including cropland, livestock production and irrigated land, accounts for more than $30 \%$ of the world's land-use cover ${ }^{80}$ Although agricultural land conversion has led to enhanced global food production and economic development, there has been an associated increase in MBD risk. ${ }^{2,81-87}$ Agricultural land has specific localised impacts on important MBD correlates such as livestock numbers and water management practices. ${ }^{80}$ In particular, livestock production, may modify MBD dynamics by increasing blood meal availability for 
the vectors ${ }^{88}$ and provide competent reservoir hosts to maintain ${ }^{76,89}$ and even amplify ${ }^{76}$ zoonotic pathogens. For instance, domestic pigs are ‘amplification' hosts for Japanese encephalitis virus (JEV) since they mount high levels of the virus in their blood which augments the proportion of infected vectors. ${ }^{89,90}$ Indeed, pig farming is reported to be a key correlate in the prevalence of JEV in Asia. ${ }^{91}$ Furthermore, livestock production may influence MBD risk via its interaction with climate change since it significantly contributes to global greenhouse gas emissions; conversely, climate change may influence disease transmission in domestic animal populations. ${ }^{44}$

Irrigation and dam creation have led to marked changes in the risk of global MBDs such as Japanese encephalitis, lymphatic filariasis (LF) and malaria. ${ }^{83,84,86,92,93}$ These practices lead to a dramatic expansion in vector breeding habitat ${ }^{94}$ and may extend disease transmission seasons, ${ }^{83}$ alter seasonal transmission dynamics in endemic areas ${ }^{86}$ and enable pathogen spread into non-endemic areas. ${ }^{91,95,96}$ However, the effects of these schemes on vector populations are complex and will also depend on vector species-specific life-history traits. ${ }^{21}$ For example, Culex quinquefasciatus, a major vector of LF in Asia, prefers to breed in clean water whereas conspecific, Culex tritaeniorhynchus, principal vector of JEV, favours stagnant water. ${ }^{97}$

Importantly, irrigation practices may also affect the socioeconomic status of a region which can influence MBD dynamics. The 'paddies paradox', whereby land conversion for irrigation leads to an initial increase and then decrease in MBD risk, has been reported for malaria in Africa $^{83}$ and Asia. ${ }^{86}$ This phenomenon is postulated to reflect increasing socioeconomic status in the region associated with improved crop production. Other possible mechanisms include changes in ecology which limit vector abundance ${ }^{98}$ and reduce pathogen spread over time. ${ }^{99}$ With future expansion of irrigation practices and dam construction expected, ${ }^{93,100,101}$ their influence on disease risk requires consideration. 


\section{Urbanisation}

The majority of recent urbanisation has occurred in developing countries, where rapid and unregulated urban settlements have caused a huge strain on public health programmes. In $2016,54 \%$ of the global population was reported to reside in urban areas; a significant increase from $34 \%$ in 1960 . This trend looks set to continue ${ }^{102}$ with 2.5 billion people predicted to augment the world's urban population by 2050, predominantly in Asia and Africa. ${ }^{103}$ Increasing numbers of people living in high densities may lead to higher overall pathogen transmission risk for some MBDs, ${ }^{104}$ while high levels of travel and trade in urban hubs can enable the spread of vectors and pathogens between population centres. ${ }^{9,104-106}$ Nevertheless, the impact of urbanisation on MBD risk is complex since evidence suggests both an expansion of some diseases and contraction of others.

For instance, urban expansion has promoted the emergence of arboviruses transmitted by Ae. aegypti, such as dengue, chikungunya and zika (Table 1), ${ }^{9,106-108}$ by influencing resource availability and climatic factors that alter mosquito community ecology. ${ }^{21}$ The phenomenon known as the urban heat island (UHI), whereby urban areas experience warmer temperatures than surrounding rural areas, ${ }^{109}$ may increase the speed of vector development. ${ }^{21}$ In addition, the interplay between the structural complexity of urban landscapes and precipitation has been associated with greater vector numbers and several dengue outbreaks in Asia. ${ }^{44}$ Vectors such as Ae. aegypti and Ae. albopictus, are well-adapted to urban areas, ${ }^{110}$ and breed in water containers, drains and gutters, with limited competition or predation. ${ }^{21}$ However, the relative impact of urbanisation on vector populations is unlikely to be geographically uniform since urban environments represent a diverse spectrum of habitat mosaics which vary in microclimatic features ${ }^{111}$ and socioeconomic status. ${ }^{21}$ 
In contrast, increased urban development has also been associated with the global decrease in malaria over the past century. ${ }^{56,112}$ However, the underlying mechanisms remains unclear. Urbanisation has been shown to reduce infectious disease burdens, likely via improved health care, education and employment when compared with rural areas. ${ }^{113}$ Nevertheless, reductions in disease risk may mask strong inequalities that exist within urban populations, especially in low and middle-income countries where urban communities with high levels of poverty show higher disease transmission than nearby rural communities. ${ }^{105}$

\section{SOCIOECONOMICS AND MOSQUITO-BORNE DISEASE RISK}

Socioeconomic factors, are increasingly recognised as further important drivers of MBD risk. ${ }^{114-116}$ For malaria, there is a strong negative association between reported disease risk and national gross domestic product per capita (GDPpc). ${ }^{115}$ This association may reflect either high rates of malaria transmission in impoverished settings or the development of poverty due to the burden of malaria on economic growth, or a combination of the two processes. ${ }^{57,115}$ Although poverty has been cited as an important factor in the spread of several arboviruses, ${ }^{116,117}$ there is a paucity of literature on this topic to support this hypothesis. ${ }^{114}$ The economic burden associated with MBDs includes direct costs of health provision and control programmes (i.e., vaccination and vector control), and indirect costs (i.e., impacts on education, demographics and human movement). ${ }^{57,115}$ Furthermore, macroeconomic costs may occur due to the influence of disease on foreign investment, trade and tourism. ${ }^{57}$

Sometimes these factors combine to impede economic development and strengthen the relationship between poverty and disease $\mathrm{5}^{57,118,119}$ leading to 'poverty traps'; a self-reinforcing mechanism enabling poverty and diseases to persist. ${ }^{120}$ This may be accelerated by the 
development of synergistic diseases referred to as syndemics, as seen with LF and HIV in East Africa. ${ }^{121}$ Escaping from these traps is particularly difficult for underprivileged rural populations who generally rely on subsistence agriculture, have poor access to healthcare and suffer high rates of infectious diseases. A further complexity arises when disease risk is a function of underlying production systems, e.g., livestock are a major feeding resource for Rift Valley Fever vectors and rice paddies are a major habitat component for JEV vectors. Since the currency of the rural poor is often biological (i.e., crops and livestock, human health and nutrition) and the dynamics of this currency can exist within ecological systems, economic development may be tied to ecological processes. ${ }^{119}$ Models representing this relationship show that 'poverty traps' are features of coupled ecological-economic systems and within these systems, infectious diseases can limit economic growth. ${ }^{119}$

External intervention (e.g., use of federal funds or international aid) can allow areas with high endemic disease burden to escape disease-poverty feedbacks. ${ }^{122}$ This economic development may then act to reduce contact between people and mosquitoes via vector protection, improved housing and environmental management (e.g., larvicide treatment, vector habitat destruction). ${ }^{3,123}$ Moreover, there is often a reduction in hazardous behaviours such as accessing high risk areas for resource exploitation or settlement. ${ }^{62}$ While the weight of evidence suggests economic growth reduces MBD risk, it also results in increased movement of people, animals and commodities, with accompanying pathogens and vectors via travel and trade. ${ }^{9,76,124,125}$

\section{THE INTERPLAY BETWEEN GLOBAL CHANGE PROCESSES: CASE STUDIES OF DENGUE AND MALARIA}


Despite growing convergence in the field of MBD research that considers interactions between global change processes,55,126 these dynamics and potential resulting trade-offs that either positively or negatively impact global health,19 are often not represented in models. Below, we outline the impact of these interactions on the global distribution of dengue which has dramatically expanded over the last 30 years and malaria which has contracted in the same period (Figure 2). This comparison helps to illustrate the fact that climate is just one part of an overall mechanism that is changing the epidemiology of MBDs.

\section{Dengue}

Although climate change is known to directly influence dengue transmission, Messina et al. ${ }^{127}$ suggested that other global change processes and their interactions with climate are likely to have a greater effect in the more immediate future. ${ }^{127}$ The rapid global emergence of dengue within the past 50 years ${ }^{128}$ is related to interacting drivers including urbanisation, socioeconomics, climate change, travel and trade. ${ }^{129,130}$ For instance, the significant expansion of urban areas after World War II, especially in Asia, meant large numbers of people migrated into cities, often residing in housing with no sanitation or running water. ${ }^{9}$ These factors, combined with poor health-care infrastructure meant that by the 1980s, dengue virus had escalated from causing sporadic epidemics to being a leading cause of morbidity and mortality in Southeast Asia. ${ }^{9}$ However, the expansion of dengue was preceded by the spread of its principal vectors, Ae. aegypti and Ae. albopictus. Originally zoophilic and sylvatic, these mosquitoes became domesticated and were introduced to global urban hubs via travel and trade. ${ }^{12,110}$ Local populations of dengue vectors then increased in urban landscapes due to the higher numbers of human hosts and the abundance of suitable breeding habitats. ${ }^{12,21}$ Furthermore, complex interplay between UHI, pesticide use and vector competition have been reported to impact vector competence and influence dengue transmission. $^{21}$ 


\section{Malaria}

Much research has pointed to interactions between malaria transmission, land conversion, socioeconomics and human movement. ${ }^{86,131,132}$ For instance, a recent study coupled MBD dynamics with socioeconomic outcomes that occurred during land transitions ${ }^{132}$ and found it was common for an initial increase in malaria transmission to occur after land-use change, followed by either a further rise or a decline in transmission. This is postulated to arise due to ecological changes that promote transmission (e.g., altered breeding sites and human-vector contact rates) occurring at a much faster rate than economic changes which can reduce transmission risk (e.g., improved housing and public health infrastructure). This analysis provided a theoretical explanation for empirical observations of higher malaria risk during the early stages of irrigation schemes compared with well-established irrigated land ${ }^{82,86}$ and highlighted the need to consider both wide-ranging sets of underlying drivers and appropriate timescales on which each driver acts on a system.

The interacting effects of climate change and socioeconomic factors are also predicted to dramatically influence malaria risk over longer timescales. A study found that the projected population at risk in 2050 was estimated to be 5.2 billion when only climatic effects were considered, 1.74 billion when only GDP effects were considered and 1.95 billion when both factors were considered. ${ }^{133}$ This indicates that climate change may act to negate the continued contraction in malaria expected with economic development. However, feedback loops between climate change and economic development need to be better understood to improve predictions.

\section{RECOMMENDATIONS FOR FUTURE RESEARCH}


Although the effects of climate change on MBD risk are significant, the influence of other global change processes and their interactions occur over shorter timescales and therefore are likely to have greater impact in the immediate future. ${ }^{134}$ Considering the effect of climate change in isolation may result in inaccurate predictions of MBD risk which may influence the formulation of robust policy recommendations for these emerging diseases. This is compounded by the fact that many studies do not account for the multiple sources of uncertainty in their predictions ${ }^{28,43}$ including the data (e.g., health, environmental and socioeconomic), future global change scenarios (e.g., climate emission scenarios), and the structure of models and their outputs.

We advocate future research to adopt a holistic system dynamics approach (Figure 3) whereby the relationships and the feedbacks between socioeconomic and environmental systems are considered. ${ }^{135}$ However, to achieve this, several research gaps need to be addressed: Firstly, enhanced surveillance and evaluation of public health measures is needed to improve health data and define the factors that promote disease risk. Secondly, empirical research is required to describe the relationships between vectors, pathogens and global change processes to improve parameterisation of MBD risk models. Thirdly, more high resolution, large-scale datasets for other global change processes are needed to match the quantity of climatic data available. Furthermore, research is required to understand the scale at which different global change processes influence MBD risk, and how to incorporate multiple scales into MBD transmission models..$^{16,28,44}$

Addressing these gaps requires improved funding for empirical research and long-term surveillance at varying geographic scales, and enhanced collaboration between researchers working within different disciplines of MBD research. In addition, greater funding for transdisciplinary studies is required to overcome unilateral modelling approaches and improve our understanding of disease risk. The ever-increasing availability of 'big data', 
sensor technology and innovative software, means researchers have the ability to understand environmental heterogeneity and global change over multiple spatial and temporal scales, including from real-time perspectives. ${ }^{136-138}$ High-resolution satellite remote sensing (RS) data is available for variables including land-use, climate and human populations at a global scale over large time periods. For example, current Sentinel satellite RS data products are available weekly at 10 metre resolution ${ }^{139}$ and can be produced into environmental datasets via machine learning approaches. Mobile phone data has also been used to map patterns and processes in human populations, ${ }^{140}$ and to examine the effect of human movement on disease transmission data. ${ }^{141}$ For example, human mobility estimates generated from mobile phone data can accurately predict the distribution and timing of dengue epidemics in Pakistan. ${ }^{141} \mathrm{In}$ addition, citizen science projects are engaging members of the public to record data such as mosquito occurrence via applications on their mobile phones. ${ }^{142,143}$

\section{CONCLUSION}

Previous MBD research has tended to focus on unilateral climate change analyses despite the growing evidence that other global change processes are important determinants of disease risk. Adopting a system dynamics approach, whereby relationships between socioeconomic and environmental drivers are considered, may improve future MBD projections and facilitate stakeholder engagement by demonstrating the effectiveness of common goals in a changing world. Enhanced funding for transdisciplinary research and new opportunities in data availability and analyses will enable a better understanding of the interacting mechanisms that drive disease transmission which will help to guide interventions and safeguard global health. ${ }^{135}$ 


\section{CONTRIBUTORS}

All authors conceived this Review. LF undertook the literature review and created figures and tables. All authors interpreted and critically revised the draft.

\section{DECLARATION OF INTERESTS}

We declare no competing interests.

\section{ACKNOWLEDGEMENTS}

The authors thank R. Gibb, S. Daly and F. Spooner for discussion and comments on the previous versions of the manuscript. This research was financially supported by the Natural Environment Research Council (NERC) [grant number NE-J001570-1] for KEJ and DWR; a PhD NERC studentship [grant number NE/L002485/1] for LF; an MRC UKRI/Rutherford Fellowship (MR/R02491X/1) and Wellcome Trust Institutional Strategic Support Fund (204841/Z/16/Z) (both DWR); IA was funded by NIHR (SRF-2011-04-001; Senior Investigator Award NF-SI-0616-10037), Medical Research Council, UK Department of Health and the Wellcome Trust. The funding sources had no involvement in the writing or decision to submit the paper for publication. IA had final responsibility for the decision to submit for publication. 


\section{SEARCH STRATEGY AND SELECTION CRITERIA}

We searched PubMed and Web of Science, for all papers from $1^{\text {st }}$ January 2014 to $28^{\text {th }}$ March 2018 inclusive to reflect the field since the publication of the WHO published 'A global brief on vector-borne diseases' in 2014 which called for further research (WHO 2014). Search terms were related to models of human mosquito-borne diseases and climate change: ("mosquito*” or "mosquito-borne disease*" or "mosquito borne disease*") AND ("climate chang*" or "climat* change*" or "climat* warm*" or "chang* climat*") AND ("model*" or "modelling"). We excluded treatment papers, reviews, case studies and surveillance reports and focused on modelling studies that evaluated the effect of climate change on mosquito borne diseases and their vectors. Climate change was defined as an alteration (either observed or projected) to climatic parameters and studies were included in the analysis if they considered the effects of climate change over several decades rather than within-decade timescales. 


\section{GLOSSARY}

Mosquito-borne disease risk: the probability that the simultaneous presence of an infected host and competent vector may impact a susceptible population. ${ }^{144}$

Correlative models of MBD: use statistical approaches to identify correlative associations of disease risk to a suite of explanatory variables such as environmental or socioeconomic conditions.

Mechanistic models of MBD: make explicit assumptions about the biological or environmental processes that drive disease risk. 


\section{TABLES}

\begin{tabular}{|l|l|l|}
\hline Disease & Mosquito vectors & Estimated or reported number of cases per annum \\
\hline Malaria & Anopheles & 212 million (148-304 million) \\
\hline Dengue & Aedes & 96 million (67-136 million) \\
\hline Lymphatic filariasis & Aedes, Anopheles, Culex & 38.5 million (31.3-46.7 million) \\
\hline Chikungunya & Aedes, Anopheles, Culex, Mansonia & 693000 \\
\hline Zika virus disease & & (Americas) \\
& Aedes & 500000 \\
\hline Yellow fever & Aedes, Haemagogus & $130000(84000-170000)$ \\
& & $($ Africa) \\
\hline Japanese encephalitis & Culex & $42500(35000-50000)$ \\
\hline West Nile fever & Culex & 2588 \\
\hline
\end{tabular}

Table 1. Number of cases per annum for the major mosquito-borne diseases of global health significance and the genera of associated mosquito vectors. Adapted from WHO 'A global brief on vector-borne diseases', ${ }^{2}$ and 'Global vector control response 2017-2030'. ' 


\section{FIGURES}
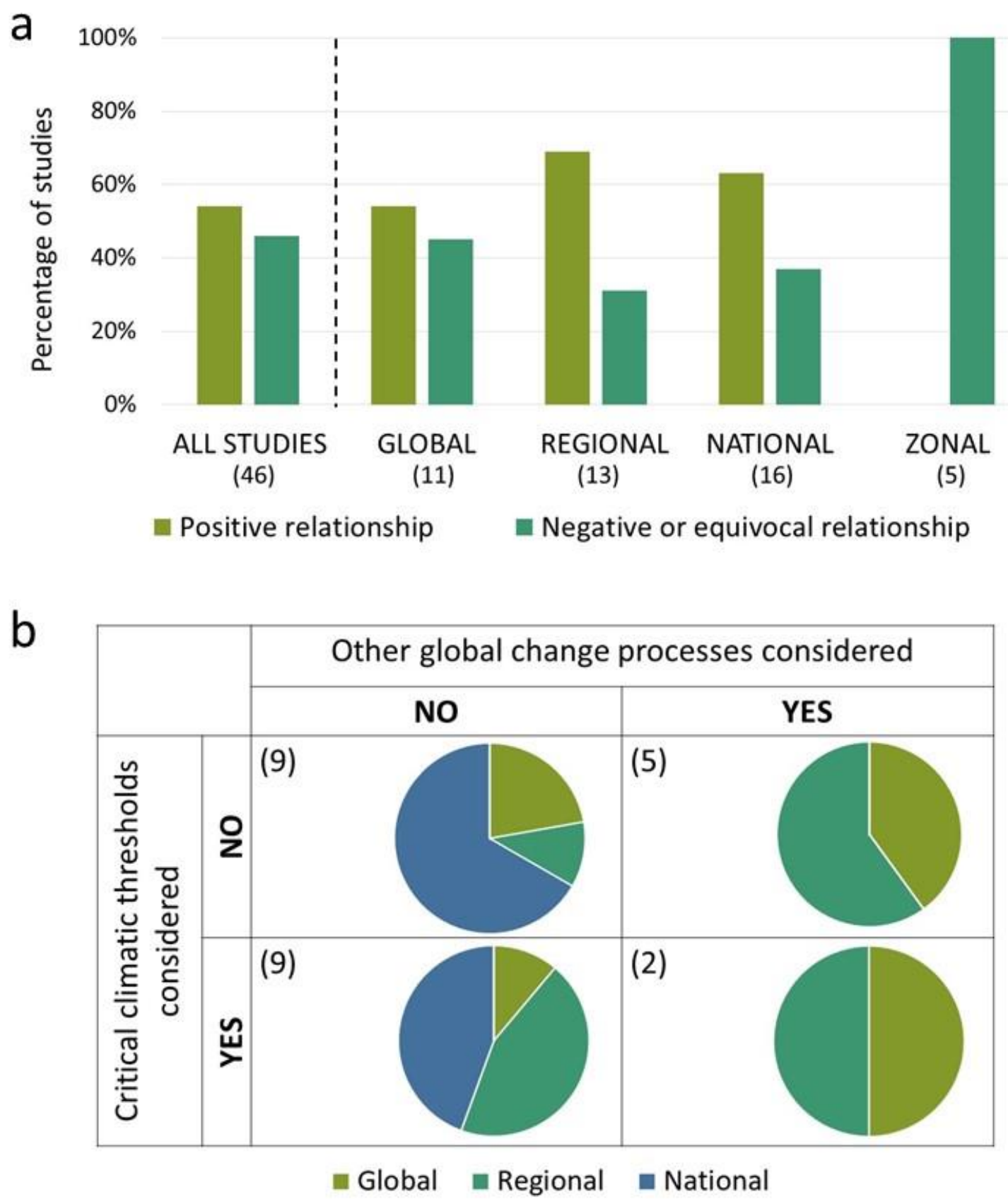

Figure 1. Systematic review of the impact of climate change on MBD risk. (a) Percentage of studies predicting a positive (light green), negative or equivocal (dark green) relationship between climate change and MBD risk per geographic region; number of studies reviewed per region are indicated in parenthesis. (b) Number of positive studies that consider the influence of other global change drivers in their models and/or critical climatic thresholds affecting the vector competence of mosquitos, per by geographic region. 


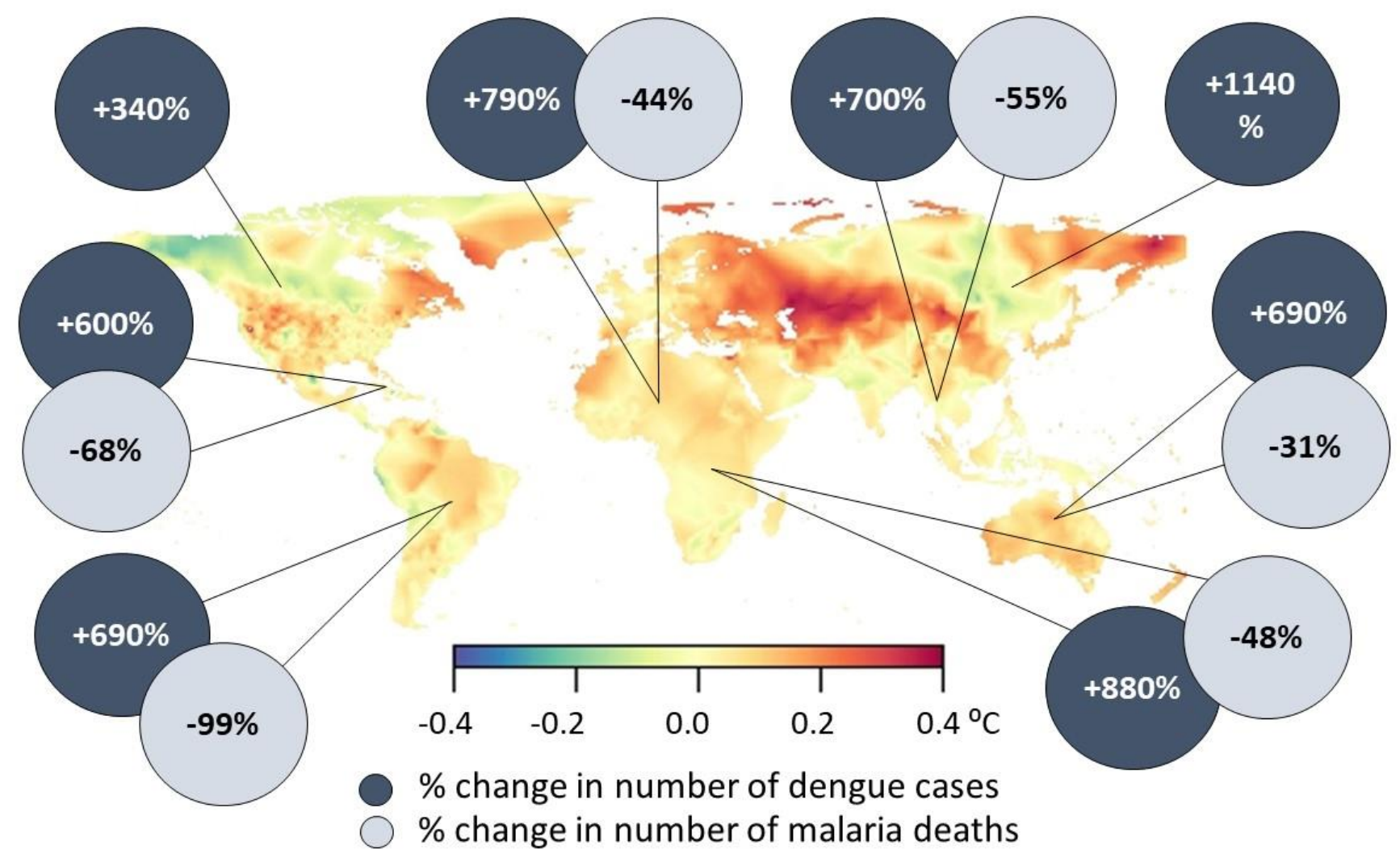

Figure 2. Percentage change in dengue cases and malaria deaths between 1993 and 2013 per WHO region overlaying annual mean land temperature $\left({ }^{\circ} \mathrm{C}\right)$ change within the same period. WHO regions include; Latin America, Caribbean, North America, North Africa and Middle East, South and Southeast Asia, Central and East Asia, Oceania, Sub-Saharam Africa. Climatic data was accessed via the Climatic Research Unit and case data retrieved from the Global Burden of Disease Survey 2013. 5,144 


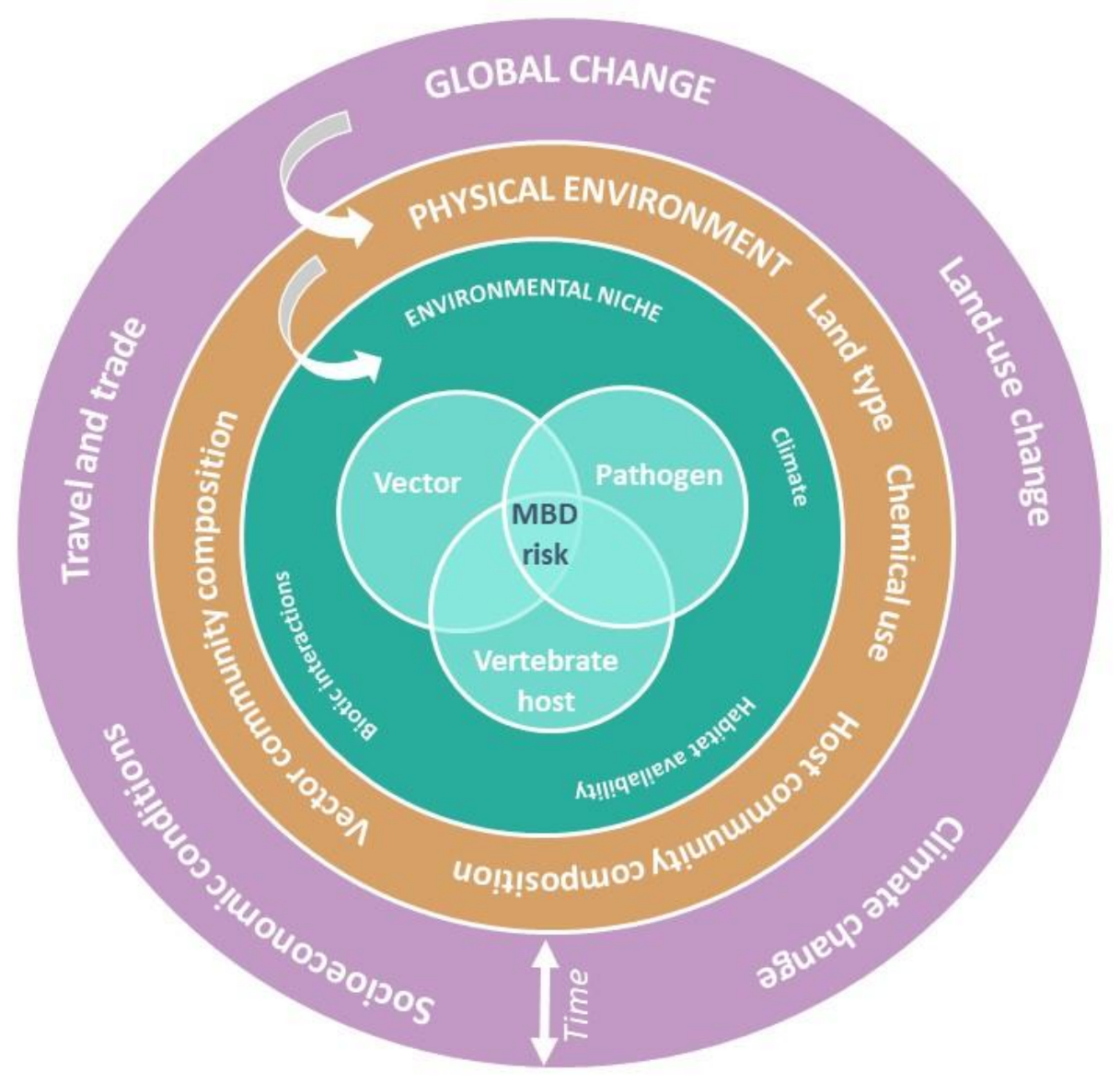

Figure 3. A system dynamics approach to understanding MBD risk. A conceptual model to show a system approach to understanding MBD risk whereby public health outcomes are influenced by complex interactions between environmental and socioeconomic systems. For disease transmission to occur requires the environmental niche of the pathogen, vector and vertebrate host to overlap. The environmental niches of these groups are influenced by the wider physical environment which varies in habitat quality and composition of vector and host (animal and human) communities. Acting on these environmental systems are major global change drivers such as land-use type, climate change, socioeconomic conditions, travel and trade that interact to influence MBD risk. 


\section{SUPPLEMENTARY MATERIALS}

Table S1. Results of systematic review of modelling studies published from 2014- March 2018, that investigated the impact of climate change on mosquito-borne disease. The table shows the spatial scale of the study, the disease and mosquito vectors, the type of model and projection and, the climatic parameters analysed. The table illustrates the direction of the relationship between the climatic parameters and the change in distribution of disease transmission risk. Details are provided regrading whether mosquito biological thresholds and other global change drivers were considered within the study. 


\section{REFERENCES}

1 WHO. Global vector control response 2017-2030. Geneva: World Health Organization; 2017.

2 WHO. A global brief on vector-borne diseases. Geneva: World Health Organization; 2014.

3 Kilpatrick AM, Randolph SE. Drivers, dynamics, and control of emerging vector-borne zoonotic diseases. Lancet 2012; 380: 1946-55.

4 Paixão ES, Teixeira MG, Rodrigues LC. Zika, chikungunya and dengue: the causes and threats of new and re-emerging arboviral diseases. BMJ Glob Heal 2017; 2: e000530.

5 Stanaway JD, Shepard DS, Undurraga EA, Halasa YA, Coffeng LE, Brady OJ, et al. The global burden of dengue: an analysis from the Global Burden of Disease Study 2013. Lancet Infect Dis 2016; 16: 712-23.

6 WHO. World Malaria Report 2017. Geneva: World Health Organization; 2017.

7 Grobbelaar AA, Weyer J, Moolla N, Van Vuren PJ, Moises F, Paweska JT. Resurgence of yellow fever in Angola, 2015-2016. Emerg Infect Dis 2016; 22: 1854-5.

8 Bhatt S, Gething PW, Brady OJ, Messina JP, Farlow AW, Moyes CL, et al. The global distribution and burden of dengue. Nature 2013; 496: 504-7.

9 Gubler DJ. Dengue, Urbanization and globalization: the unholy trinity of the 21(st) century. Trop Med Health 2011; 39: 3-11.

10 Longbottom J, Browne AJ, Pigott DM, Sinka ME, Golding N, Hay SI, et al. Mapping the spatial distribution of the Japanese encephalitis vector, Culex tritaeniorhynchus Giles, 1901 (Diptera: Culicidae) within areas of Japanese encephalitis risk. Parasit Vectors 2017; 10: 148.

11 Campbell LP, Luther C, Moo-Llanes D, Ramsey JM, Danis-Lozano R, Peterson AT. Climate change influences on global distributions of dengue and chikungunya virus vectors. Philos Trans R Soc B Biol Sci 2015; 370: 20140135.

12 Kraemer MUG, Sinka ME, Duda KA, Mylne AQN, Shearer FM, Barker CM, et al. The global distribution of the arbovirus vectors Aedes aegypti and Ae. albopictus. Elife 2015; 4: 1-18.

13 Brady OJ, Golding N, Pigott DM, Kraemer MUG, Messina JP, Reiner Jr RC et al. Global temperature constraints on Aedes aegypti and Ae . albopictus persistence and competence for dengue virus transmission. Parasit Vector 2014; 7: 338.

14 Christiansen-Jucht C, Parham PE, Saddler A, Koella JC, Basáñez M-G. Temperature during larval development and adult maintenance influences the survival of Anopheles gambiae s.s. Parasit Vectors 2014; 7: 489.

15 Mordecai E, Cohen J, Evans M V, Gudapati P, Johnson LR, Miazgowicz K, et al. Detecting the impact of temperature on transmission of Zika, dengue, and chikungunya using mechanistic models. PLOS Neg Trop Dis 2017; 11: e0005568.

16 Parham PE, Waldock J, Christophides GK, Hemming D, Agusto F, Evans KJ, et al. Climate, environmental and socio-economic change: weighing up the balance in vector-borne disease transmission. Philos Trans R Soc B Biol Sci 2015; 370: 20130551.

17 Gottdenker NL, Streicker DG, Faust CL, Carroll CR. Anthropogenic land use change and infectious diseases: A Review of the Evidence. Ecohealth 2014; 11: 619-32.

18 Newbold T. Future effects of climate and land-use change on terrestrial vertebrate community diversity under different scenarios. Proc R Soc London B Biol Sci 2018; 285: 20180792.

19 Whitmee S, Haines A, Beyrer C, Boltz F, Capon AG, De Souza Dias BF, et al. Safeguarding human health in the Anthropocene epoch: Report of the Rockefeller Foundation-Lancet Commission on planetary health. Lancet 2015; 386: 1973-2028. 
20 Lounibos LP, Juliano SA. Where vectors collide: the importance of mechanisms shaping the realized niche for modeling ranges of invasive Aedes mosquitoes. Biol Invasions 2018; 1 -17.

21 Ladeau SL, Allan BF, Leisnham PT, Levy MZ, Management NR, Science E. The ecological foundations of transmission potential and vector- borne disease in urban landscapes. Funct Ecol 2015; 889-901.

22 Tjaden NB, Caminade C, Beierkuhnlein C, Thomas SM. Mosquito-borne diseases: advances in modelling climate-change impacts. Trends Parasitol 2017; 34: 227-45.

23 Bates M. The natural history of mosquitoes. New York: Harper and Row Publishers; 1949.

24 Lo Iacono G, Cunningham AA, Bett B, Grace D, Redding DW, Wood JLN. The environmental limits of Rift Valley Fever revealed using eco-epidemiological mechanistic models. PNAS 2018; July: 201803264.

25 IPCC. Summary for policymakers. In: Climate Change 2014: Impacts, adaptation, and vulnerability. Part A: Global and sectoral aspects. Contribution of Working Group II to the Fifth Assessment Report of the Intergovernmental Panel on Climate Change. [Field CB, Barros VR, Dokken DJ, Mach KJ, Mastrandrea MB, Bilir TE, et al (eds.)]. Cambridge, United Kingdom and New York, NY, USA: Cambridge University Press; 2014; p. 1-32. Available from: https://www.ipcc.ch/pdf/assessmentreport/ar5/wg2/ar5_wgII_spm_en.pdf

26 Tjaden NB, Suk JE, Fischer D, Thomas SM, Beierkuhnlein C, Semenza JC. Modelling the effects of global climate change on Chikungunya transmission in the 21 st century. Sci Rep 2017; 7: 3813.

27 Paz S. Climate change impacts on West Nile virus transmission in a global context. Philos Trans R Soc B Biol Sci 2015; 370: 20130561.

28 Caminade C, Kovats S, Rocklov J, Tompkins AM, Morse AP, Colón-González FJ, et al. Impact of climate change on global malaria distribution. Proc Natl Acad Sci 2014; 111: 3286-91.

29 Watts N, Amann M, Ayeb-Karlsson S, Belesova K, Bouley T, Boykoff M, et al. The Lancet Countdown on health and climate change: From 25 years of inaction to a global transformation for public health. Lancet 2017; 6736: 32464-9.

30 Paaijmans KP, Blanford S, Chan BHK, Thomas MB. Warmer temperatures reduce the vectorial capacity of malaria mosquitoes. Biol Lett 2012; 8: 465-8.

31 Ewing DA, Cobbold CA, Purse B V., Nunn MA, White SM. Modelling the effect of temperature on the seasonal population dynamics of temperate mosquitoes. $J$ Theor Biol 2016; 400: 65-79.

32 Paaijmans KP, Heinig RL, Seliga RA, Blanford JI, Blanford S, Murdock CC, et al. Temperature variation makes ectotherms more sensitive to climate change. Glob Chang Biol 2013; 19: 2373-80

33 Westbrook CJ, Reiskind MH, Pesko KN, Greene KE, Lounibos LP. Larval environmental temperature and the susceptibility of Aedes albopictus Skuse (Diptera: Culicidae) to Chikungunya virus. Vector borne zoonotic Dis 2010; 10: 241-7.

34 Murdock CC, Paaijmans KP, Bell AS, King JG, Hillyer JF, Read AF, et al. Complex effects of temperature on mosquito immune function. Proc R Soc B Biol Sci 2012; 279: 3357-66.

35 Ohm JR, Baldini F, Barreaux P, Lefevre T, Lynch PA, Suh E, et al. Rethinking the extrinsic incubation period of malaria parasites. Parasit Vectors 2018; 11: 1-9.

36 Barbazan P, Guiserix M, Boonyuan W, Tuntaprasart W, Pontier D, Gonzalez J. Modelling the effect of temperature on transmission of dengue. Med Vet Entomol 2010; 24: 6673. 
37 Tjaden NB, Thomas SM, Fischer D, Beierkuhnlein C. Extrinsic incubation period of dengue: knowledge, backlog, and applications of temperature dependence. PLoS Negl Trop Dis 2013; 7: e2207.

38 Reisen WK, Fang Y, Martinez VM. Effects of Temperature on the transmission of west nile virus by Culex tarsalis (Diptera: Culicidae). J Med Entomol 2006; 43: 309-17.

39 Carrington LB, Armijos MV, Lambrechts L, Scott TW. Fluctuations at a low mean temperature accelerate dengue virus transmission by Aedes aegypti. PLoS Negl Trop Dis 2013; 7: e2190.

40 Lambrechts L, Paaijmans KP, Fansiri T, Carrington LB, Kramer LD, Thomas MB, et al. Impact of daily temperature fluctuations on dengue virus transmission by Aedes aegypti. Proc Natl Acad Sci 2011; 108: 7460-5.

41 Paaijmans KP, Blanford S, Bell AS, Blanford JI, Read AF, Thomas MB. Influence of climate on malaria transmission depends on daily temperature variation. Proc Natl Acad Sci USA 2010; 107: 15135-9.

42 IPCC. Summary for Policymakers. In: Climate Change 2013: The Physical Science Basis. Contribution of Working Group I to the Fifth Assessment Report of the Intergovernmental Panel on Climate Change. [Stocker TF, Qin D, Plattner G, Tignor MMB, Allen SK, Boschung J, et al (eds.)]. Cambridge, United Kingdom and New York, NY, USA: Cambridge University Press; 2013; p. 1-33.

43 Harris RMB, Grose MR, Lee G, Bindoff NL, Porfirio LL, Fox-Hughes P. Climate projections for ecologists. Wiley Interdiscip Rev Clim Chang 2014; 5: 621-37.

44 Booth M. Climate change and the neglected tropical diseases. 1st ed. Advances in Parasitology. Elsevier Ltd.; 2018. 1-88 p.

45 Davis JK, Vincent G, Hildreth MB, Kightlinger L, Carlson C WM. Integrating environmental monitoring and mosquito surveillance to predict vector-borne disease: prospective forecasts of a West Nile virus outbreak. PLOS Curr Outbreaks 2017; Edition 1.

46 Stewart Ibarra AM, Ryan SJ, Beltrán E, Mejía R, Silva M, Muñoz Á. Dengue vector dynamics (Aedes aegypti) influenced by climate and social factors in ecuador: implications for targeted control. PLoS One 2013; 8: e78263.

47 Day JF, Shaman J. Using hydrologic conditions to forecast the risk of focal and epidemic arboviral transmission in peninsular Florida. J Med Entomol 2008; 45: 458-65.

48 Soti V, Tran A, Degenne P, Chevalier V, Lo Seen D, Thiongane Y. Combining hydrology and mosquito population models to identify the drivers of Rift Valley fever emergence in semi-arid regions of West Africa. PLoS Negl Trop Dis 2012; 6: e1795.

49 Asare EO, Tompkins AM, Bomblies A. A regional model for malaria vector developmental habitats evaluated using explicit, pond-resolving surface hydrology simulations. PLoS One 2016; 11: e0150626.

50 Siraj A, Santos-Vega M, Bouma MJ, Yadeta D, Ruiz Carrascal D, Pascual M. Altitudinal changes in malaria incidence in highlands of Ethiopia and Colombia. Science 2014; 343: 1154-8.

51 Lowe R, Stewart-Ibarra AM, Petrova D, García-Díez M, Borbor-Cordova MJ, Mejía R, et al. Climate services for health: predicting the evolution of the 2016 dengue season in Machala, Ecuador. Lancet Planet Heal 2017;1: e142-51.

52 Dobson A. Climate variability, global change, immunity, and the dynamics of infectious diseases. Ecology 2009; 90: 920-7.

53 Peterson AT. Biogeography of diseases: A framework for analysis. Naturwissenschaften 2008; 95: 483-91. 
54 Warren R, Price J, Graham E, Forstenhaeusler N, VanDerWal J. The projected effect on insects, vertebrates, and plants of limiting global warming to $1.5^{\circ} \mathrm{C}$ rather than $2^{\circ} \mathrm{C}$. Science 2018; 360: 791-5.

55 Campbell-Lendrum D, Manga L, Bagayoko M, Sommerfeld J. Climate change and vectorborne diseases: what are the implications for public health research and policy? Philos Trans $R$ Soc London 2015; 370: 20130552.

56 Tatem AJ, Gething PW, Smith DL, Hay SI. Urbanization and the global malaria recession. Malaria J 2013; 12: 133.

57 Sachs J, Malaney P. The economic and social burden of malaria. Nature 2002; 415: 680 .

58 Steffen W, Grinevald J, Crutzen P, Mcneill J. The anthropocene: Conceptual and historical perspectives. Philos Trans R Soc A 2011; 369: 842-67.

59 Gibb R, Moses LM, Redding DW, Jones KE. Understanding the cryptic nature of Lassa fever in West Africa. Pathog Glob Health 2017; 111: 276-88

60 Hassell JM, Begon M, Ward MJ, Fèvre EM. Urbanization and disease emergence: dynamics at the wildlife-livestock-human interface. Trends Ecol Evol 2016; 32: 1-13.

61 Johnson PTJ, de Roode JC, Fenton A. Why infectious disease research needs community ecology. Science 2015; 349: 1259504.

62 Lambin EF, Tran A, Vanwambeke SO, Linard C, Soti V. Pathogenic landscapes: interactions between land, people, disease vectors, and their animal hosts. Int $J$ Health Geogr 2010; 9: 54.

63 Hudson LN, Newbold T, Contu S,Hill SLL, Lysenko I, De Palma A et al. The PREDICTS database : a global database of how local terrestrial biodiversity responds to human impacts. Ecol Evol 2014; 4: 1-35.

64 Jones KE, Patel NG, Levy MA, Storeygard A, Balk D, Gittleman JL, et al. Global trends in emerging infectious diseases. Nat Lett 2008; 451: 990-4.

65 Fornace KM, Abidin TR, Alexander N, Brock P, Grigg MJ, Murphy A, et al. Association between landscape factors and spatial patterns of Plasmodium knowlesi infections in Sabah, Malaysia. Emerg Infect Dis J 2016; 22: 201.

66 Chaves LSM, Conn JE, López RVM, Sallum MAM. Abundance of impacted forest patches less than $5 \mathrm{~km}^{2}$ is a key driver of the incidence of malaria in Amazonian Brazil. Sci Rep 2018; 8: 1-11.

67 Newbold T, Hudson LN, Hill SLL, Contu S, Lysenko I, Senior R a, et al. Global effects of land use on local terrestrial biodiversity. Nature 2015; 520: 45-50.

68 Roche B, Rohani P, Dobson AP, Guégan JF. The impact of community organization on vector-borne pathogens. Am Nat 2013; 181: 1-11.

69 Wilcox BA, Gubler DJ. Disease ecology and the global emergence of zoonotic pathogens. Environ Health Prev Med 2005; 10: 263-72.

70 Ostfeld RS, Keesing F. Biodiversity and disease risk: the case of lyme disease. Conserv Biol 2000; 14: 722-8.

71 Civitello DJ, Cohen J, Fatima H, Halstead NT, Liriano J, McMahon TA, et al. Biodiversity inhibits parasites: Broad evidence for the dilution effect. Proc Natl Acad Sci 2015; 112: 8667-71.

72 Faust CL, Dobson AP, Gottdenker N, Bloomfield LSP, McCallum HI, Gillespie TR, et al. Null expectations for disease dynamics in shrinking habitat: dilution or amplification? Philos Trans R Soc B Biol Sci 2017; 372: 20160173.

73 Randolph SE, Dobson ADM. Pangloss revisited: a critique of the dilution effect and the biodiversity-buffers-disease paradigm. Parasitology 2012; 139: 847-63.

74 Luis AD, Kuenzi AJ, Mills JN. Species diversity concurrently dilutes and amplifies transmission in a zoonotic host-pathogen system through competing mechanisms. Proc Natl Acad Sci 2018; 115:7979-84. 
75 Burkett-Cadena ND, Vittor AY. Deforestation and vector-borne disease: Forest conversion favors important mosquito vectors of human pathogens. Basic Appl Ecol 2017; 26: 101-10.

76 Patz JA, Graczyk TK, Geller N, Vittor AY. Effects of environmental change on emerging parasitic diseases. Int J Parasitol 2000; 30: 1395-405.

77 Brouard O, Le Jeune A-H, Leroy C, Cereghino R, Roux O, Pelozuelo L, et al. Are algae relevant to the detritus-based food web in tank-bromeliads? PLoS One 2011; 6: e20129.

78 Rueda Páramo ME, López Lastra CC, García JJ. Persistence and pathogenicity of a native isolate of Leptolegnia chapmanii against Aedes aegypti larvae in different anthropic environments. Biocontrol Sci Technol 2015; 25: 238-43.

79 Loaiza JR, Dutari LC, Rovira JR, Sanjur OI, Laporta GZ, Pecor J, et al. Disturbance and mosquito diversity in the lowland tropical rainforest of central Panama. Sci Rep 2017; 7: 1-13.

80 Hurtt GC, Chini LP, Frolking S, Betts RA, Feddema J, Fischer G, et al. Harmonization of land-use scenarios for the period 1500-2100: 600 years of global gridded annual landuse transitions, wood harvest, and resulting secondary lands. Clim Change 2011; 109: $117-61$.

81 WHO. Agricultural Development and vector-borne diseases training and information materials on vector biology and control. Geneva: World Health Organization; 1996. http://www.who.int/water_sanitation_health/resources/agridevbegin.pdf

82 Lindblade KA, Walker ED, Onapa AW, Katungu J, Wilson ML. Land use change alters malaria transmission parameters by modifying temperature in a highland area of Uganda. Trop Med Int Heal. 2000;5(4):263-74.

83 Ijumba JN, Lindsay SW. Impact of irrigation on malaria in Africa: Paddies paradox. Med Vet Entomol 2001; 15: 1-11.

84 Erlanger TE, Keiser J, Caldas De Castro M, Bos R, Singer BH, Tanner M, et al. Effect of water resource development and management on lymphatic filariasis, and estimates of populations at risk. Am J Trop Med Hyg 2005; 73: 523-33.

85 Keiser J, De Castro MC, Maltese MF, Bos R, Tanner M, Singer BH, et al. Effect of irrigation and large dams on the burden of malaria on a global and regional scale. Am J Trop Med Hyg 2005; 72: 392-406.

86 Baeza A, Bouma MJ, Dobson AP, Dhiman R, Srivastava HC, Pascual M. Climate forcing and desert malaria: the effect of irrigation. Malar J 2011; 10: 190.

87 Jaleta KT, Hill SR, Seyoum E, Balkew M, Gebre-Michael T, Ignell R, et al. Agroecosystems impact malaria prevalence: large-scale irrigation drives vector population in western Ethiopia. Malar J 2013; 12: 350.

88 Service MW. Agricultural development and arthropod-borne diseases: a review. Rev Saude Publica 1991; 25: 165-78.

89 Le Flohic G, Porphyre V, Barbazan P, Gonzalez JP. Review of Climate, Landscape, and Viral Genetics as Drivers of the Japanese Encephalitis Virus Ecology. PLoS Negl Trop Dis 2013; 7: 5-11.

90 Buescher EL, Scherer WF, Rosenberg MZ, McClure HE. Immunologic studies of Japanese encephalitis virus in Japan. III. Infection and antibody response of birds. $J$ Immunol 1959; 83: 605-13.

91 Erlanger TE, Weiss S, Keiser J, Utzinger J, Wiedenmayer K. Past, present, and future of Japanese encephalitis. Emerg Infect Dis 2009; 15: 1-7.

92 Keiser J, Maltese MF, Erlanger TE, Bos R, Tanner M, Singer BH, et al. Effect of irrigated rice agriculture on Japanese encephalitis, including challenges and opportunities for integrated vector management. Acta Trop 2005; 95: 40-57. 
93 Kibret S, Lautze J, McCartney M, Nhamo L, Wilson GG. Malaria and large dams in subSaharan Africa: future impacts in a changing climate. Malar J 2016; 15: 448.

94 Patz JA, Daszak P, Tabor GM, Aguirre AA, Pearl M, Epstein J, et al. Unhealthy landscapes: Policy recommendations on land use change and infectious disease emergence. Environ Health Perspect 2004; 112: 1092-8.

95 Fuller DO, Parenti MS, Hassan AN, Beier JC. Linking land cover and species distribution models to project potential ranges of malaria vectors: an example using Anopheles arabiensis in Sudan and Upper Egypt. Malar J 2012; 11: 264.

96 van den Hurk AF, Ritchie SA, Mackenzie JS. Ecology and geographical expansion of Japanese encephalitis virus. Annu Rev Entomol 2009; 54: 17-35.

97 Bashar K, Rahman MS, Nodi IJ, Howlader AJ. Species composition and habitat characterization of mosquito (Diptera: Culicidae) larvae in semi-urban areas of Dhaka, Bangladesh. Pathog Glob Health 2016; 110: 48-61.

98 Chase JM, Knight TM. Drought-induced mosquito outbreaks in wetlands. Ecol Lett 2003; 6: 1017-24.

99 Moore SM, Borer ET, Hosseini PR. Predators indirectly control vector-borne disease: linking predator-prey and host-pathogen models. J R Soc Interface 2010; 7: 161-76.

100 Alexandratos N, Bruinsma J. World agriculture towards 2030/2050: the 2012 revision. Rome; 2012. ESA Working paper No. 12-03. Available from: http://www.fao.org/fileadmin/templates/esa/Global_persepctives/world_ag_2030_50_2 012_rev.pdf

101 Anderson EP, Jenkins CN, Heilpern S, Maldonado-ocampo JA, Carvajal-vallejos FM, Encalada AC, et al. Fragmentation of Andes-to-Amazon connectivity by hydropower dams. Sci Adv 2018; 4: 1-8.

102 The World Bank. The United Nations Population Divisions World Urbanization Prospects: Urban population (\% of total). 2016 [Date accessed:21 Feb 2018]. Available from: https://data.worldbank.org/indicator/SP.URB.TOTL.IN.ZS?view=chart

103 United Nations, Department of Economic and Social Affairs, Population Division. World Urbanization Prospects: The 2014 Revision, Highlights (ST/ESA/SER.A/352). New York; 2014.

104 Weaver SC, Reisen WK. Present and future arboviral threats. Antiviral Res 2010; 85: 328-45.

105 Saker L, Lee K, Cannito B, Gilmore A, Campbell-Lendrum D. Globalization and infectious diseases: a review of the linkages. Geneva; 2004.

106 Weaver SC. Urbanization and geographic expansion of zoonotic arboviral diseases: Mechanisms and potential strategies for prevention. Trends Microbiol 2013; 21: 360 3.

107 Hotez PJ. Global urbanization and the neglected tropical diseases. PLoS Negl Trop Dis 2017; 11: 1-5.

108 Kwa BH. Environmental change, development and vectorborne disease: Malaysia's experience with filariasis, scrub typhus and dengue. Environ Dev Sustain 2008; 10: 209-17.

109 Imhoff ML, Zhang P, Wolfe RE, Bounoua L. Remote sensing of the urban heat island effect across biomes in the continental USA. Remote Sens Environ 2010; 114: 504-13.

110 Brown JE, McBride CS, Johnson P, Ritchie S, Paupy C, Bossin H, et al. Worldwide patterns of genetic differentiation imply multiple "domestications" of Aedes aegypti, a major vector of human diseases. Proc R Soc B Biol Sci 2011; 278: 2446-54.

111 Murdock CC, Evans M V, McClanahan TD, Miazgowicz KL, Tesla B. Fine-scale variation in microclimate across an urban landscape shapes variation in mosquito 
population dynamics and the potential of Aedes albopictus to transmit arboviral disease. PLoS Negl Trop Dis 2017; 11: e0005640.

112 Qi Q, Guerra CA, Moyes CL, Elyazar IARF, Gething PW, Hay SI, et al. The effects of urbanization on global Plasmodium vivax malaria transmission. Malar J 2012; 11: 403.

113 Wood CL, McInturff A, Young HS, Kim D, Lafferty KD. Human infectious disease burdens decrease with urbanization but not with biodiversity. Philos Trans $R$ Soc Lond B Biol Sci 2017; 372: 20160122.

114 Mulligan K, Dixon J, Sinn C-LJ, Elliott SJ. Is dengue a disease of poverty? A systematic review. Pathog Glob Health 2015; 109: 10-8.

115 Gallup JL, Sachs JD. The economic burden of malaria. Am J Trop Med Hyg 2001; 64: 85-96.

116 Oviedo-Pastrana M, Méndez N, Mattar S, Arrieta G, Gomezcaceres L. Epidemic outbreak of Chikungunya in two neighboring towns in the Colombian Caribbean: a survival analysis. Arch Public Heal 2017; 75: 1.

117 WHO. First WHO report on neglected tropical diseases: working to overcome the global impact of neglected tropical diseases. World Health Organization 2010; 1-184.

118 Alsan MM, Westerhaus M, Herce M, Nakashima K, E.Farmer P. Poverty,Globlal Health and infectious Disease:Lessons from Haiti and Rwanda. Infect Dis Clin North Am 2012; 25: 611-22.

119 Ngonghala CN, De Leo GA, Pascual MM, Keenan DC, Dobson AP, Bonds MH. General ecological models for human subsistence, health and poverty. Nat Ecol Evol 2017; 1: 1153-9.

120 Bowles S, Durlauf S, Hoff K, eds. Poverty Traps. Princeton: Princeton University Press; 2006.

121 Singer M, Bulled N. Interlocked infections: the health burdens of syndemics of neglected tropical diseases. Ann Anthropol Pract 2013; 36: 328-45.

122 Bloom DE, Canning D, Sevilla J. The effect of health on economic growth: A production function approach. World Dev 2004; 32: 1-13.

123 Tolle MA. Mosquito-borne diseases. Curr Probl Pediatr Adolesc Health Care 2009; 39: 97-140.

124 Nunes MRT, Palacios G, Faria NR, Sousa EC, Pantoja JA, Rodrigues SG, et al. Air Travel Is Associated with Intracontinental Spread of Dengue Virus Serotypes 1-3 in Brazil. PLoS Negl Trop Dis. 2014;8(4).

125 Kampen H, Jansen S, Schmidt-Chanasit J, Walther D. Indoor development of Aedes aegypti in Germany, 2016. Eurosurveillance 2016; 21: 2-4.

126 Gregory N, Ewers RM, Chung AYC, Cator LJ. El Niño drought and tropical forest conversion synergistically determine mosquito development rate. Environ. Res. Lett. 2019: in press; doi:10.1088/1748-9326/ab0036.

127 Messina JP, Brady OJ, Pigott DM, Golding N, Kraemer MUG, Scott TW, et al. The many projected futures of dengue. Nat Rev Microbiol 2015; 13: 230-9.

128 WHO. Global strategy for dengue prevention and control 2012-2020. World Health Organization 2012.

129 Guzman MG, Harris E. Dengue. Lancet 2015; 385: 453-65.

130 Ebi KL, Nealon J. Dengue in a changing climate. Environ Res 2016; 151: 115-23.

131 Stratton L, O’Neill MS, Kruk ME, Bell ML. The persistent problem of malaria: Addressing the fundamental causes of a global killer. Soc Sci Med 2008; 67: 854-62.

132 Baeza A, Santos-Vega M, Dobson AP, Pascual M. The rise and fall of malaria under land-use change in frontier regions. Nat Ecol Evol 2017; 1: 108.

133 Béguin A, Hales S, Rocklöv J, Åström C, Louis VR, Sauerborn R. The opposing effects 
of climate change and socio-economic development on the global distribution of malaria. Glob Environ Chang 2011; 21: 1209-14.

134 Millennium Ecosystem Assessment. Ecosystems and human well-being: synthesis. Island Press, Washington, DC, 2005.

135 Pongsiri MJ, Gatzweiler FW, Bassi AM, Haines A, Demassieux F. The need for a systems approach to planetary health. Lancet Planet Heal 2017; 1: e257-9.

136 Fleming L, Tempini N, Gordon-Brown H, Nichols GL, Sarran C, Vineis P, et al. Big data in environment and human health. Oxford Res Encycl Environ Sci 2017; July: 1-27.

137 Hay SI, George DB, Moyes CL, Brownstein JS. Big data opportunities for global infectious disease surveillance. PLoS Med 2013; 10: 2-5.

138 Kraemer MUG, Hay SI, Pigott DM, Smith DL, Wint GRW, Golding N. Progress and challenges in infectious disease cartography. Trends Parasitol 2016; 32: 19-29.

139 European Space Agency. Sentinel-1. 2018 [Date accessed:25 Feb 2018]. Available from: https://sentinel.esa.int/web/sentinel/missions/sentinel-1

140 Pekel J-F, Cottam A, Gorelick N, Belward AS. High-resolution mapping of global surface water and its long-term changes. Nature 2016; 540: 418-22.

141 Deville P, Linard C, Martin S, Gilbert M, Stevens FR, Gaughan AE. Dynamic population mapping using mobile phone data. PNAS 2014; 111: 15888-93.

142 Wesolowski A, Qureshi T, Boni MF, Roe P, Johansson MA, Basit S. Impact of human mobility on the emergence of dengue epidemics in Pakistan. PNAS 2015; 112: 1188792.

143 Palmer JRB, Oltra A, Collantes F, Delgado JA, Lucientes J, Delacour S, et al. Citizen science provides a reliable and scalable tool to track disease-carrying mosquitoes. Nat Commun 2017; 8: 916.

144 Mukundarajan H, Hol FJH, Castillo EA, Newby C, Prakash M. Using mobile phones as acoustic sensors for high-throughput mosquito surveillance. Elife 2017; 6: e27854.

145 Bergquist R, Stensgaard AS, Rinaldi L. Vector-borne diseases in a warmer world: Will they stay or will they go? Geospatial Heal 2018; 13: 699. 
Table S1. Results of systematic review of modelling studies published from 2014- March 2018, that investigated the impact of climate change on mosquito-borne disease. The table shows the spatial scale of the study, the disease and mosquito vectors, the type of model and projection and, the climatic parameters analysed.

The table illustrates the direction of the relationship between the climatic parameters and the burden of disease or vectors. Details are provided regrading whether mosquito biological thresholds and other global change drivers were considered within the study.

\begin{tabular}{|c|c|c|c|c|c|c|c|c|}
\hline $\begin{array}{l}\text { SPATIAL } \\
\text { SCALE and } \\
\text { AUTHORS }\end{array}$ & DISEASE & $\begin{array}{l}\text { MOSQUITO } \\
\text { VECTORS }\end{array}$ & $\begin{array}{c}\text { MODEL } \\
\text { TYPE }\end{array}$ & $\begin{array}{c}\text { STUDY } \\
\text { PROJECTION }\end{array}$ & $\begin{array}{l}\text { CLIMATE } \\
\text { PARAMETERS } \\
\text { INCLUDED }\end{array}$ & $\begin{array}{c}\text { DIRECTION OF } \\
\text { RELATIONSHIP } \\
\text { (+ or -) }\end{array}$ & $\begin{array}{l}\text { CONSIDERED } \\
\text { CRITICAL } \\
\text { CLIMATE } \\
\text { THRESHOLDS* }\end{array}$ & $\begin{array}{c}\text { CONSIDERED } \\
\text { OTHER GLOBAL } \\
\text { CHANGE DRIVERS }\end{array}$ \\
\hline \multicolumn{9}{|l|}{ ZONAL } \\
\hline \multicolumn{9}{|l|}{ Australia } \\
\hline (1) & Dengue & Aedes aegypti & Mechanistic & Prospective & $\mathrm{T}, \mathrm{P}, \mathrm{H}$ & (equivocal) & $\mathrm{Y}$ & $\mathrm{N}$ \\
\hline (2) & MVEV & Culex annulirostris & Mechanistic & Prospective & $\mathrm{T}, \mathrm{P}, \mathrm{H}$ & - & $\mathrm{Y}$ & $\mathrm{Y}^{\#}$ \\
\hline \multicolumn{9}{|l|}{ China } \\
\hline (3) & $(N A)$ & Aedes albopictus & Mechanistic & Retrospective & $\mathrm{T}$ & $+/-$ & $\mathrm{Y}$ & $\mathrm{N}$ \\
\hline \multicolumn{9}{|l|}{ Kenya } \\
\hline (4) & Malaria & $(N A)$ & Mechanistic & Prospective & $\mathrm{T}$ & $+/-$ & $\mathrm{Y}$ & $\mathrm{N}$ \\
\hline (5) & RVF & $\begin{array}{c}\text { Culex } \\
\text { quinquefasciatus, } \\
\text { Culex univitattus, } \\
\text { Mansonia africana, } \\
\text { Mansonia uniformis }\end{array}$ & Correlative & Prospective & $\mathrm{T}, \mathrm{P}$ & $+/-$ & $\mathrm{N}$ & $\mathrm{Y}^{\delta}$ \\
\hline \multicolumn{9}{|l|}{ Spain } \\
\hline (6) & $(N A)$ & $\begin{array}{c}\text { Anopheles } \\
\text { atroparvus, Culex } \\
\text { pipiens, Culex } \\
\text { theileri, Culex } \\
\text { modestus, } \\
\text { Culex perexiguus, } \\
\text { Ochlerotatus caspius, } \\
\text { Ochlerotatus detritus }\end{array}$ & Correlative & Prospective & T, P, H, W, S, E, Ph & (equivocal) & $\mathrm{N}$ & $\mathrm{N}$ \\
\hline \multicolumn{9}{|l|}{ NATIONAL } \\
\hline \multicolumn{9}{|l|}{ Australia } \\
\hline (7) & (NA) & Ae. albopictus & $\begin{array}{c}\text { Hybrid } \\
\text { correlative }\end{array}$ & Prospective & T, P, S, Sm & + & $\mathrm{Y}$ & $\mathrm{N}$ \\
\hline (8) & Dengue & $(N A)$ & Mechanistic & Prospective & $\mathrm{T}, \mathrm{P}, \mathrm{H}$ & - & $\mathrm{Y}$ & $\mathrm{N}$ \\
\hline
\end{tabular}




\begin{tabular}{|c|c|c|c|c|c|c|c|c|}
\hline \multicolumn{9}{|c|}{ Brazil } \\
\hline (9) & Dengue & Ae. aegypti & Correlative & Prospective & $\mathrm{T}, \mathrm{P}$ & - & $\mathrm{N}$ & $\mathrm{N}$ \\
\hline \multicolumn{9}{|c|}{ Germany } \\
\hline (10) & $(N A)$ & Ae. albopictus & Correlative & Prospective & $\mathrm{T}, \mathrm{P}$ & + & $\mathrm{N}$ & $\mathrm{N}$ \\
\hline \multicolumn{9}{|l|}{ Iran } \\
\hline (11) & Malaria & Anopheles spp. & Correlative & Retrospective & $\mathrm{T}, \mathrm{P}, \mathrm{H}$ & $+/-$ & $\mathrm{N}$ & $\mathrm{N}$ \\
\hline \multicolumn{9}{|c|}{ Mexico } \\
\hline (12) & $(N A)$ & Ae. albopictus & Correlative & Prospective & $\mathrm{T}, \mathrm{P}$ & + & $\mathrm{N}$ & $\mathrm{N}$ \\
\hline (13) & Dengue & Ae. aegypti & Correlative & Prospective & $\mathrm{T}, \mathrm{P}$ & + & $\mathrm{N}$ & $\mathrm{N}$ \\
\hline \multicolumn{9}{|c|}{$\begin{array}{l}\text { Republic of } \\
\text { Korea }\end{array}$} \\
\hline (14) & Malaria & $(N A)$ & Mechanistic & Retrospective & $\mathrm{T}$ & + & $\mathrm{N}$ & $\mathrm{N}$ \\
\hline \multicolumn{9}{|c|}{ Serbia } \\
\hline (15) & $(N A)$ & Ae. albopictus & Mechanistic & Prospective & $\mathrm{T}, \mathrm{P}, \mathrm{Ph}$ & $+/-$ & $\mathrm{Y}$ & $\mathrm{N}$ \\
\hline \multicolumn{9}{|c|}{ Taiwan } \\
\hline (16) & JEV & $(N A)$ & Correlative & Retrospective & $\mathrm{T}, \mathrm{P}, \mathrm{H}, \mathrm{Ph}$ & + & $\mathrm{N}$ & $\mathrm{N}$ \\
\hline \multicolumn{9}{|c|}{ Tanzania } \\
\hline (17) & Dengue & Ae. aegypti & Correlative & Prospective & $\mathrm{T}, \mathrm{P}$ & + & $\mathrm{N}$ & $\mathrm{N}$ \\
\hline (18) & RVF & $\begin{array}{c}\text { Culex } \\
\text { pipiens complex }\end{array}$ & Correlative & Prospective & $\mathrm{T}, \mathrm{P}$ & $+/-$ & $\mathrm{N}$ & $\mathrm{N}$ \\
\hline \multicolumn{9}{|c|}{ United Kingdom } \\
\hline (19) & $(N A)$ & Cx.pipiens & Mechanistic & Prospective & $\mathrm{T}$ & + & $\mathrm{Y}$ & $\mathrm{N}$ \\
\hline \multicolumn{9}{|l|}{ USA } \\
\hline (20) & WNV & $\begin{array}{c}\text { Cx. pipiens, Culex } \\
\text { tarsalis }\end{array}$ & Mechanistic & Prospective & $\mathrm{T}, \mathrm{P}$ & + & $\mathrm{Y}$ & $\mathrm{N}$ \\
\hline (21) & Dengue & Ae. aegypti & Mechanistic & Prospective & $\mathrm{T}, \mathrm{P}$ & + & $\mathrm{Y}$ & $\mathrm{N}$ \\
\hline (22) & $(N A)$ & Ae. albopictus & Mechanistic & Prospective & $\mathrm{T}, \mathrm{Ph}$ & - & $\mathrm{Y}$ & $\mathrm{N}$ \\
\hline \multicolumn{9}{|c|}{ REGIONAL } \\
\hline \multicolumn{9}{|c|}{ Africa } \\
\hline (23) & Malaria & Anopheles arabiensis & Correlative & Prospective & $\mathrm{T}, \mathrm{P}$ & - & $\mathrm{N}$ & $\mathrm{N}$ \\
\hline
\end{tabular}




\begin{tabular}{|c|c|c|c|c|c|c|c|c|}
\hline (24) & Malaria & An. gambiae & Mechanistic & Prospective & $\mathrm{T}$ & + & $\mathrm{Y}$ & $\mathrm{Y}^{¥}$ \\
\hline \multicolumn{9}{|c|}{ Europe } \\
\hline (25) & $(N A)$ & Ae. albopictus & Correlative & Prospective & $\mathrm{T}, \mathrm{P}$ & + & $\mathrm{N}$ & $\mathrm{Y}^{\epsilon}$ \\
\hline (26) & Dengue & $(N A)$ & Correlative & Prospective & $\mathrm{T}, \mathrm{P}, \mathrm{H}$ & + & $\mathrm{N}$ & $\mathrm{Y}^{\beta}$ \\
\hline (27) & WNV & Ae. albopictus & Correlative & Prospective & $\mathrm{T}, \mathrm{P}$ & + & $\mathrm{N}$ & $\mathrm{N}$ \\
\hline (28) & $(N A)$ & Ae. albopictus & Mechanistic & Prospective & $\mathrm{T}, \mathrm{P}, \mathrm{H}$ & + & $\mathrm{Y}$ & $\mathrm{N}$ \\
\hline (29) & $(N A)$ & $\begin{array}{l}\text { Aedes albopictus, } \\
\text { Aedes japonicus }\end{array}$ & Correlative & Prospective & $\mathrm{T}, \mathrm{P}$ & $+/-$ & $\mathrm{N}$ & $\mathrm{N}$ \\
\hline (30) & (NA) & Ae. albopictus & Correlative & Prospective & $\mathrm{T}, \mathrm{P}, \mathrm{Ph}$ & + & $\mathrm{Y}$ & $\mathrm{N}$ \\
\hline (31) & Dengue & $\begin{array}{l}\text { Ae. aegypti, Ae. } \\
\text { albopictus }\end{array}$ & Mechanistic & $\begin{array}{l}\text { Retrospective and } \\
\text { prospective }\end{array}$ & $\mathrm{T}$ & + & $\mathrm{Y}$ & $\mathrm{N}$ \\
\hline (32) & WNV & $(N A)$ & Correlative & Prospective & $\mathrm{T}$ & + & $\mathrm{N}$ & $\mathrm{Y}^{\gamma}$ \\
\hline \multicolumn{9}{|c|}{ North America } \\
\hline (33) & $(N A)$ & Ae. albopictus & Mechanistic & Prospective & $\mathrm{T}, \mathrm{P}$ & + & $\mathrm{Y}$ & $\mathrm{N}$ \\
\hline \multicolumn{9}{|c|}{ South America } \\
\hline (34) & Malaria & Anopheles spp. & Correlative & Prospective & $\mathrm{T}, \mathrm{P}$ & $+/-$ & $\mathrm{N}$ & $\mathrm{Y}^{\delta}$ \\
\hline \multicolumn{9}{|c|}{$\begin{array}{l}\text { South and } \\
\text { Southeast Asia }\end{array}$} \\
\hline (35) & Malaria & Anopheles spp. & $\begin{array}{l}\text { Hybrid } \\
\text { correlative }\end{array}$ & Prospective & $\mathrm{T}, \mathrm{P}, \mathrm{H}$ & $+/-$ & $\mathrm{Y}$ & $\mathrm{N}$ \\
\hline \multicolumn{9}{|c|}{ GLOBAL } \\
\hline (36) & $(N A)$ & Ae. aegypti & Mechanistic & Prospective & $\mathrm{T}$ & $+/-$ & $\mathrm{Y}$ & $\mathrm{N}$ \\
\hline (37) & Dengue & Ae. aegypti & Correlative & Prospective & $\mathrm{T}, \mathrm{P}, \mathrm{H}$ & $+/-$ & $\mathrm{Y}$ & $\mathrm{N}$ \\
\hline (38) & $(N A)$ & Ae. aegypti & Correlative & Prospective & $\mathrm{T}, \mathrm{P}$ & + & $\mathrm{N}$ & $\mathrm{N}$ \\
\hline (39) & $(N A)$ & $\begin{array}{l}\text { Ae. aegypti, Ae. } \\
\text { albopictus }\end{array}$ & Correlative & Prospective & $\mathrm{T}, \mathrm{P}$ & + & $\mathrm{N}$ & $\mathrm{N}$ \\
\hline (40) & Zika, Dengue & $\begin{array}{l}\text { Ae. aegypti, Aedes } \\
\text { africanus, Ae. } \\
\text { albopictus }\end{array}$ & Correlative & Prospective & $\mathrm{T}, \mathrm{P}$ & + & $\mathrm{N}$ & $\mathrm{Y}^{\delta}$ \\
\hline (41) & Malaria & $\begin{array}{l}\text { An. gambiae, } \\
\text { Anopheles } \\
\text { stephensi }\end{array}$ & Correlative & Prospective & $\mathrm{T}$ & - & $\mathrm{Y}$ & $\mathrm{N}$ \\
\hline (42) & $\begin{array}{l}\text { WNV, LF, } \\
\text { SLEV }\end{array}$ & Cx. quinquefasciatus & Correlative & Prospective & $\mathrm{T}, \mathrm{P}$ & $+/-$ & $\mathrm{N}$ & $\mathrm{N}$ \\
\hline (43) & Zika & c, Ae. albopictus & Mechanistic & Retrospective & $\begin{array}{c}\text { T, P, } \\
\text { El Nino event }\end{array}$ & + & $\mathrm{Y}$ & $\mathrm{N}$ \\
\hline (44) & $(N A)$ & Cx. quinquefasciatus & Mechanistic & Theoretical & $\mathrm{P}$ & $+/-$ & $\mathrm{Y}$ & $\mathrm{N}$ \\
\hline
\end{tabular}




\begin{tabular}{|l|c|c|c|c|c|c|c|}
\hline$(45)$ & Chikungunya & $(N A)$ & Correlative & Prospective & T, P & + \\
\hline$(46)$ & $(N A)$ & Ae. aegypti & Correlative & Prospective & T, P & $+\mathrm{Y}^{\lambda}$ \\
\hline
\end{tabular}

Abbreviations: (NA), data not available; MVEV, Murray Valley encephalitis virus; RVF, Rift valley fever; JEV, Japanese encephalitis virus; SLEV, St Louis encephalitis virus; LF, lymphatic filariasis; WNV, West Nile virus; T, temperature; P, precipitation; H, humidity; W, wind; S, solar radiation; E, evapotranspiration; Ph, photoperiod; Sm, soil moisture;

*Inclusion of critical climate thresholds that may impact specific vector life history traits (e.g. temperature thresholds for mosquito survival).

\# Land cover, human population density; animal host migration

${ }^{\delta}$ Land cover

${ }^{\ddagger}$ Land cover, human population density

${ }^{€}$ Trade

${ }^{\beta}$ Human population density, urbanisation, GDP per capita

$\gamma$ Land cover, animal host migration

${ }^{\lambda}$ Human population density 


\section{REFERENCES}

1 Williams CR, Mincham G, Ritchie SA, Viennet E, Harley D. Bionomic response of Aedes aegypti to two future climate change scenarios in far north Queensland, Australia: implications for dengue outbreaks. Parasit Vectors 2014; 7: 447.

2 Ho SH, Speldewinde P, Cook A. A Bayesian Belief Network for Murray Valley encephalitis virus risk assessment in Western Australia. Int J Health Geogr 2016; 15: 6.

3 Jia P, Chen X, Chen J, Lu L, Liu Q, Tan X. How does the dengue vector mosquito Aedes albopictus respond to global warming? Parasit Vectors 2017; 10: 140.

4 Paaijmans KP, Blanford JI, Crane RG, Mann ME, Ning L, Schreiber K V, et al. Downscaling reveals diverse effects of anthropogenic climate warming on the potential for local environments to support malaria transmission. Clim Change 2014; 125: 479-88.

Ochieng AO, Nanyingi M, Kipruto E, Ondiba IM, Amimo FA, Oludhe C, et al. Ecological niche modelling of Rift Valley fever virus vectors in Baringo, Kenya. Infect Ecol Epidemiol 2016; 6: 32322.

6 Roiz D, Ruiz S, Soriguer R, Figuerola J. Climatic effects on mosquito abundance in Mediterranean wetlands. Parasit Vectors 2014; 7: 333.

$7 \quad$ Hill MP, Axford JK, Hoffmann AA. Predicting the spread of Aedes albopictus in Australia under current and future climates: Multiple approaches and datasets to incorporate potential evolutionary divergence. Austral Ecol 2013; 39: 469-78.

Williams Cr, Mincham G, Faddy H, Viennet E, Ritchie Sa, Harley D. Projections of increased and decreased dengue incidence under climate change. Epidemiol Infect 2016; 144: 3091-3100.

9 Cardoso-Leite R, Vilarinho AC, Novaes MC, Tonetto AF, Vilardi GC, Guillermo-Ferreira R. Recent and future environmental suitability to dengue fever in Brazil using species distribution model. Trans R Soc Trop Med Hyg 2014; 108: 99-104.

10 Koch LK, Cunze S, Werblow A, Kochmann J, Dörge DD, Mehlhorn H, et al. Modeling the habitat suitability for the arbovirus vector Aedes albopictus (Diptera: Culicidae) in Germany. Parasitol Res 2016; 115: 957-64. 

vectors during the past 5 decades in Iran. Acta Trop 2017; 166: 45-53.

Pech-May A, Moo-Llanes DA, Puerto-Avila MB, Casas M, Danis-Lozano R, Ponce G, et al. Population genetics and ecological niche of invasive Aedes albopictus in Mexico. Acta Trop 2016; 157: 30-41.

Equihua M, Ibáñez-Bernal S, Benítez G, Estrada-Contreras I, Sandoval-Ruiz CA, Mendoza-Palmero FS. Establishment of Aedes aegypti (L.) in mountainous regions in Mexico: Increasing number of population at risk of mosquito-borne disease and future climate conditions. Acta Trop 2017; 166: 316-27.

14 Linthicum KJ, Anyamba A, Killenbeck B, Lee W-J, Lee HCS, Klein TA, et al. Association of temperature and historical dynamics of malaria in the Republic of Korea, including reemergence in 1993. Mil Med 2014; 179: 806-14. establishment of the Asian tiger mosquito (Aedes albopictus) in Serbia. Clim Change 2017; 142: 361-74.

Lin C-L, Chang H-L, Lin C-Y, Chen K-T. Seasonal patterns of Japanese encephalitis and associated meteorological factors in Taiwan. Int J Environ Res Public Health 2017; 14: 1317.

Mweya CN, Kimera SI, Stanley G, Misinzo G, Mboera LEG. Climate change influences potential distribution of infected Aedes aegypti co-occurrence with dengue epidemics risk areas in Tanzania. PLoS One 2016; 11: 1-13.

18 Mweya CN, Mboera LEG, Kimera SI. Climate influence on emerging risk areas for Rift Valley fever epidemics in Tanzania. Am J Trop Med Hyg 2017; 97: 109-114.

19 Ewing DA, Cobbold CA, Purse B V., Nunn MA, White SM. Modelling the effect of temperature on the seasonal population dynamics of temperate mosquitoes. J Theor Biol 2016; 400: 65-79. vectors. Earth Interact 2015; 19: 1-18.

21 Butterworth MK, Morin CW, Comrie AC. An analysis of the potential impact of climate change on dengue transmission in the southeastern United States. Environ Health Perspect 2017; 125: 579-85. 
Yee DA, Ezeakacha NF, Abbott KC. The interactive effects of photoperiod and future climate change may have negative consequences for a wide-spread invasive insect. Oikos 2017; 126: 40-51.

Ryan SJ, McNally A, Johnson LR, Mordecai EA, Ben-Horin T, Paaijmans K, et al. Mapping physiological suitability limits for malaria in Africa under climate change. Vector Borne Zoonotic Dis 2015; 15: 718-25.

Thomas SM, Tjaden NB, van den Bos S, Beierkuhnlein C. Implementing cargo movement into climate based risk assessment of vectorborne diseases. Int J Environ Res Public Health 2014; 11: 3360-74.

Bouzid M, Colón-González FJ, Lung T, Lake IR, Hunter PR. Climate change and the emergence of vector-borne diseases in Europe: case study of dengue fever. BMC Public Health 2014; 14: 781.

Trájer A, Bede-Fazekas Á, Bobvos J, Páldy A. Seasonality and geographical occurrence of West Nile fever and distribution of Asian tiger mosquito. Idojaras 2014; 118: 19-40.

Proestos Y, Christophides GK, Erguler K, Tanarhte M, Waldock J, Lelieveld J. Present and future projections of habitat suitability of the Asian tiger mosquito, a vector of viral pathogens, from global climate simulation. Philos Trans R Soc B Biol Sci 2015; 370: 20130554.

Cunze S, Koch LK, Kochmann J, Klimpel S. Aedes albopictus and Aedes japonicus - two invasive mosquito species with different temperature niches in Europe. Parasit Vectors 2016; 9: 573.

Cunze S, Kochmann J, Koch LK, Klimpel S. Aedes albopictus and its environmental limits in Europe. PLoS One 2016; 11: e0162116.

Liu-Helmersson J, Quam M, Wilder-Smith A, Stenlund H, Ebi K, Massad E, et al. Climate change and Aedes vectors: 21st century projections for dengue transmission in Europe. EBioMedicine 2016; 7: 267-77.

Semenza JC, Tran A, Espinosa L, Sudre B, Domanovic D, Paz S. Climate change projections of West Nile virus infections in Europe: implications for blood safety practices. Environ Health 2016; 15: 28. 

future scenarios. Parasit Vectors 2015; 8: 426.

Khormi HM, Kumar L. Future malaria spatial pattern based on the potential global warming impact in South and Southeast Asia. Geospat Health 2016; 11: 290-8.

Liu-Helmersson J, Stenlund H, Wilder-Smith A, Rocklöv J. Vectorial capacity of Aedes aegypti: effects of temperature and implications for global dengue epidemic potential. PLoS One 2014; 9: e89783.

Khormi H, Kumar L. Climate change and the potential global distribution of Aedes aegypti: spatial modelling using geographical information system and CLIMEX. Geospat Health 2014; 8: 405-15. dengue and chikungunya virus vectors. Philos Trans R Soc B Biol Sci 2015; 370: 20140135.

40 Carlson CJ, Dougherty ER, Getz W. An ecological assessment of the pandemic threat of zika virus. PLoS Negl Trop Dis 2016; 10: 1-18.

41 Murdock CC, Sternberg ED, Thomas MB. Malaria transmission potential could be reduced with current and future climate change. Sci Rep 2016; 6: 27771.

42 Samy AM, Elaagip AH, Kenawy MA, Ayres CFJ, Peterson AT, Soliman DE, et al. Climate change influences on the global potential distribution of the mosquito Culex quinquefasciatus, vector of West Nile virus and lymphatic filariasis. PLoS One 2016; 11: e0163863.

43 Caminade C, Turner J, Metelmann S, Hesson JC, Blagrove MSC, Solomon T, et al. Global risk model for vector-borne transmission of Zika virus reveals the role of El Niño 2015. Proc Natl Acad Sci 2017; 11: 119-24.

44 Valdez LD, Sibona GJ, Diaz LA, Contigiani MS, Condat CA. Effects of rainfall on Culex mosquito population dynamics. J Theor Biol 2017; 421: 28-38.

45 Tjaden NB, Suk JE, Fischer D, Thomas SM, Beierkuhnlein C, Semenza JC. Modelling the effects of global climate change on Chikungunya transmission in the 21st century. Sci Rep 2017; 7: 3813. 
Monaghan AJ, Sampson KM, Steinhoff DF, Ernst KC, Ebi KL, Jones B, et al. The potential impacts of 21st century climatic and population changes on human exposure to the virus vector mosquito Aedes aegypti. Clim Change 2018; 146: 487-500. 